\title{
nature
}

\section{Does Britain belong to Europe?}

The past few weeks of dispute about financial policies have confirmed Britain's posture as the odd man out of Europe. Perhaps that is what the British really want.

THE British appear to be digging themselves into a geographically untenable position over their dealings with their European neighbours and among themselves. So much appears to be the only tenable inference from last week's prolongation of the dispute, between the prime minister and her chancellor of the exchequer about the conduct of international monetary policy. Not that last week's instalment of the dispute was any more overt than that preceding the budget in March. The British government naturally denies that there can be a serious dispute at such an august level, and the public signs are all the other way. Last week, for example, Mrs Margaret Thatcher was telling anybody who would stop and listen that Mr Nigel Lawson, the chancellor, is an excellent fellow (or, at least, a "brilliant" one), while Lawson did nothing more provocative than deliver an academic address on the benefits of a free market containing a few sentences implying that governments should sometimes intervene in markets (currency markets in particular).

That was the immediate issue last March, when the chancellor sought to link the British currency more securely with the West German, and when the prime minister believed that the cost of tying the two together would be outrageously high. Like the most interesting quarrels, both may have been correct. In March, when sterling, the British currency, seemed likely to rise too quickly and too far, Mrs Thatcher's ready-reckoning led her to conclude that preventing water running uphill in this way would require a great quantity of sterling to be sold for then unwanted dollars or other denominations, probably without long-term benefit but probably at great loss. The chancellor's view was that high-priced sterling would undermine the recently restored competitiveness of British industry, to the general discomfort, short and long-term. Complicated questions often have this attribute of seeming reasonable from all sides. In the event, the British dispute was caused by a sudden collapse in the strength of sterling (did the quarrel contribute to it?), since when there has been a revival of anxiety about inflation, a countervailing sharp increase of interest rates and now, again, the prospect of more trouble in keeping sterling stable.

\section{Difficulties}

Although, on the face of things, these money troubles are arcane, they are proxies for much more deep-seated difficulties in the relationship between Britain and its European neighbours. The immediate connection is the system for regulating European currencies called the European Monetary System, to which Britain has chosen not to belong. It is an open secret that the British chancellor of the exchequer wants Britain to belong as do many other members of the government. The case for membership is not merely the currency stability that follows but the financial disciplines that stability requires. The case against is that in such a system. the cost of stability could be greater than that of fluctuations, while the financial disciplines are but infringements of sovereignty named differently. At least for the time being, there is no prospect of Britain joining the system.

That is the long-term paradox. Like the other members of the European Communities, Britain is committed to being part of a thoroughly common market from 1 January 1992, essentially an attempt to win the commercial benefits of the United States without a federal constitution. The British seem quite eager to enjoy the fruits of this liberalization of the market, but they do not want the inevitable obligations: a particular issue that has stuck in the British government's throat is that the creation of a truly common market entails uniform rates of value-added tax. So, as on many other occasions in recent decades, Britain is a half-hearted member of a European organization (the European high-energy physics laboratory or CERN, the European Space Agency, the European framework programme of research run from Brussels, are some examples). This is a recipe for the worst of all worlds: membership brings obligations, but mean diffidence means missed opportunities for moulding international institutions in an acceptable way.

For a government as disaffected as the British, it is never difficult to find good logic for hanging back. The European Monetary System will not indefinitely make sense without a European reserve bank (which prospect is now being studied). Can there be such a thing as a European foreign policy without European defence forces? And can there be a European policy on the encouragement of useful science without common mechanisms for supporting basic research? The need cannot indefinitely be overlooked.

Although the presenting symptoms of the present quarrel within the British government are fiscal and monetary, the consequences will thus not leave the professional community indefinitely untouched. One danger for the British and for the rest of the European Communities is that the mainland and offshore parts of Europe will get so far out of step in the coming decade that important opportunities for the more efficient division of labour will be neglected. One illustration of the difficulties that may arise is last week's decision in Britain not to continue spending on fast reactor research (see next page) at a level comparable with that required to sustain effective membership of the European partnership which the government agreed to join only five years ago. Now there seems also to have been trouble about the scale of British participation in the thermonuclear fusion programme. While it is permissible for a member of an international partnership to jib at some proposals for common action, it is difficult to jib at every proposal without, at some stage, letting membership lapse. But is that what the British want?

Maybe it is. In the past decade and more, Britain seems to have been hankering after what can only seem a different path of social development from the mainland partners. Where else in Europe is it considered virtuous to spend time and energy in centralizing control of publicly supported universities, at the same time reducing their capacity, when there is plainly emerging a chronic shortage of new skills of the kinds that universities exist to foster? Where else is the government's budget in surplus while people who wish to go on holiday cannot do so undelayed for lack of adequate air traffic control, and cannot make their way by road instead for lack of public investment? Even the new channel tunnel, due to open in 1992, will be unapproachable by fast train from the British side until many years after it has been finished. It seems odd behaviour. 